\title{
UNIVERSALLY DESIGNED RESIDENTIAL ENVIRONMENT FOR SENIOR CITIZENS - SOME GUIDELINES FOR PRACTICE ACCORDING TO CHOSEN RESEARCH
}

\author{
Marek NIEZABITOWSKI \\ Silesian University of Technology, Faculty of Organization and Management, Department of Applied Social \\ Sciences; Marek.Niezabitowski@polsl.pl, ORCID: 0000000277302483
}

Purpose: The aim of the article is to present empirical arguments supporting the thesis that universally designed residential environment (housing estate, building, house, nursing home etc.) if has to be friendly for elderly people it has an inclusive impact on them, liquidates barriers of satisfaction of their needs and also satisfies the needs of other age groups.

Design/methodology/approach: The analyses presented in the article are based on the idea of universal design applicable to housing environment. Data used in these analyses come from several research projects in which the author was personally involved as a member of a research team or the head. These are both qualitative (in-depth interviews) and quantitative data (surveys) gathered during the studies conducted on chosen housing estates in Silesia (Southern Poland).

Findings: According to these analyses substantial percentages of senior inhabitants of the three housing estates in Katowice may live without needed support in their late years when this support is necessary and crucial. Moreover the respondents of presented studies stated that they experience barriers to their mobility in a building or in their housing estate. As they want to be a part of a local community of their estates and they need more support as they get older some of them desire to live close to young people in their residential environment.

Research limitations/implications: As the population of many housing estates are constantly aging and the adjustment of the infrastructure of existing and built housing estates to the needs of different age groups becomes a significant future challenge, SWOT analyses of the estates dedicated to these groups (including senior citizens) should be commissioned by the management crews of these estates.

Originality/value: The studies presented in the article show what qualities specific for senior citizens should be included in residential environments currently created and planned for future. The text is addressed to professionals like e.g. sociologists, architects, who are interested in the process of creation of residential environment adjusted to the needs of different groups of inhabitants including elderly people.

Keywords: elderly people, residential environment, universal design, housing estate for both young and elderly residents.

Category of the paper: research paper. 


\section{Introduction}

The residential environment is very important for the quality of life of elderly people, that is why shaping it according to the needs of seniors is an important priority. Confirmation of this significance are both certain social policy documents as well as gerontological research and ideas related to these problems (issues) of everyday life in seniors.

These are the four example facts which are the evidence of this importance ${ }^{1}$ :

1. Firstly, this subject has always been addressed by all nationwide large-scale gerontological research carried out so far in our country, including those under the aegis of the Polish Gerontological Society. I am thinking of research from 1967-1968 (Piotrowski, 1973) under the guidance of prof. Jerzy Piotrowski, research from 1999-2001 (Synak, 2003) under the guidance of prof. Bruno Synak and PolSenior research from 2007-2011 (Mossakowska, Więcek, and Błędowski, 2012) under the guidance of prof. Piotr Błędowski.

2. Secondly, large international Enable-Age research ${ }^{2}$ shows that seniors spend more and more time in their apartment as they get older, which demonstrates the importance of the quality of the nearest living environment for the quality of life of the elderly, and furthermore confirms the sense of the idea of ' Aging in place".

3. Thirdly, Madrid International Plan of Action on Aging (United Nations, 2002) links closely the quality of life of older people to their residential environment, as it exposes housing environment and habitat as one of the themes/issues under the priority: creating a favorable and supportive environment (Szatur-Jaworska, 2012).

4. Fourthly, certain social policy solutions and EU programs implemented in different countries meet this priority because they are focused on the best adaptation of the architectural environment and infrastructure and services to the needs and limitations of the elderly, so that they can stay as long as possible in the current, home environment. Good examples are the solutions, institutions or practices such as: two strategies of the British government: "Lifetime homes, lifetime neighborhoods", or housing strategy ("Laying the foundations. A housing strategy for England"), promoting and supporting an independent life of senior citizens in their housing environment (Stula, 2012). Similarly, the French project entitled "Vivre chez soy" (to live in the house for as long as possible) was focused on creating solutions conducive to the intensification of the use of intelligent devices supporting the safe and independent life of the elderly (Stula, 2012).

\footnotetext{
${ }^{1}$ This list of facts, which are the evidence of the essentiality of the issues of the residential environment and its impact on the quality of life of elderly people in scientific research and social policy has been presented in: Niezabitowski, 2018b, p. 27.

${ }^{2}$ Enable-Age project, focused on housing environment of elderly people, has been conducted in the years 20012004 by research teams from Sweden, Germany, Great Britain, Hungary and Latvia (see Scheidt, Windley, 2006).
} 
The last two facts mentioned above emphasize/postulate shaping the living environment, taking into account the limitations of physical efficiency occurring in the elderly. One of the concepts of universal design developed by the architect Selwyn Goldsmith (Goldsmith, 1963, 1997, 2000) contained precisely this aspect of creating the architecture and urban environment. It was about supporting the comfortable movement of disabled and elderly people in the buildings and creating architectural facilities free of barriers (impediments). In turn, in the 1990s in Sweden, due to the growing awareness of the effects of demographic aging and the postulates resulting from them of adapting buildings and cities to functional limitations, a special tool was created to assess flats and architectural objects in terms of their accessibility for people with these limitations. This scaled tool taking into account various types of limitations of physical fitness occurs under the name Housing Enabler (Iwarsson, and Slaug, 2001).

The further development of the idea of universal design meant that this idea today in the field of architecture and urban planning not only takes into account the limitations of people with disabilities and the elderly, but also covers the needs of other diverse groups of residents (Building for Everyone - universaldesign.ie/Built-Environment/Building-for-Everyone). The point is, I think, also that a well-designed living environment has an inclusive impact on both senior citizens and other potential residents regardless of their age and the condition and type of physical fitness's limitations.

In order to present arguments for a universally designed residential environment for the elderly, I will use empirical material collected during several research projects in which I personally participated as a contractor or was their head. These were mainly 4 projects: the PolSenior (2007-2011) ${ }^{3}$ nationwide research subproject conducted in selected Upper

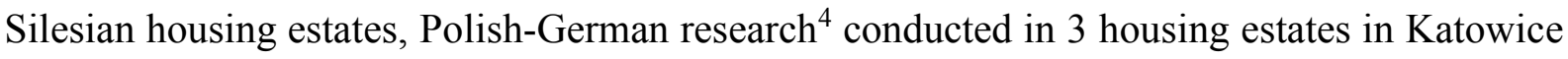
(2011-2012), research carried out at the "Zandka" housing estate in Zabrze (2009-2010) ${ }^{5}$ and

\footnotetext{
${ }^{3}$ Research work financed from funds for science in the years 2007-2011 as a commissioned research project PBZMEiN-9/2/2006, carried out under the guidance of prof. dr hab. Piotr Błędowski from the Warsaw School of Economics. As a result of the project, the monograph was created: Mossakowska, Więcek, and Błędowski (eds.) (2012). Head of the sub-project entitled Kapital spoleczny seniorów w warunkach różnych środowisk urbanistycznych a wymogi ich dostosowania do aktywizacji życiowej i jakościowego zabezpieczenia potrzeb ludzi starych [The social capital of seniors in the conditions of various urban environments and the requirements of their adaptation to life activation and qualitative protection of the needs of old people] was dr hab. Adam Bartoszek, prof. University of Silesia from the Institute of Sociology of the University of Silesia, and the performers prof. dr hab. Eng. arch. Elżbieta Niezabitowska, dr inż. arch. Beata Kucharczyk-Brus and dr Marek Niezabitowski from the Silesian University of Technology. The result of the research (within this subproject) was the monograph: Niezabitowska, Bartoszek, Kucharczyk-Brus, and Niezabitowski (2013).

${ }^{4}$ Polish-German project with the symbol UE7 / Rar-3/2011 entitled Yesterday, today and tomorrow Polish and German large housing estates. A comparative study of urban development models and their acceptance on the example of Katowice and Leipzig (2011-2012), funded by the Polish-German Foundation for Science (project number given by the Foundation: 2010-21). Project manager: prof. dr hab. Eng. arch. Elżbieta Niezabitowska. Participants in the project on the Polish side are dr hab. Adam Bartoszek (professor at the University of Silesia), dr eng. arch. Beata Kucharczyk-Brus, dr eng. arch. Beata Komar, dr Marek Niezabitowski. Participants on the German side are prof. dr hab. Sigrun Kabisch, Dr. Katrin Grossman, Dr. Annegret Hasse from Helmholtz Zentrum für Umweltforschung (UFZ) in Leipzig.

${ }^{5}$ Research work with the symbol NB-207/ROZ-2/2009 entitled People and institutions in the process of transforming the urban local community. A sociological study on the example of the Zandka estate in Zabrze (2009-2010) commissioned by the Zabrze City Hall. The research was carried out by a team from the Department of Applied Social Sciences of the Silesian University of Technology composed of: dr Marek Niezabitowski
} 
my own research project on the adaptation of Catholic priests to retirement in the dioceses of the Silesian Voivodeship (2009-2014) ${ }^{6}$. As a part of the Poland-wide research sub-project of PolSenior, the research team carried out 166 questionnaire interviews and 31 free interviews with older residents of three settlements in Upper Silesia (the "Superjednostka" estate in Katowice, the patronage estate for railwaymen in "Zatorze" in Gliwice, and the former stateowned farm estate in Poniszowice near Gliwice). In turn, in the case of the Polish-German project, empirical material encompasses 589 questionnaire interviews and 100 in-depth interviews, including 22 with older residents (aged 60 and over) of three housing estates in Katowice (the Tysiąclecie estate, the Paderewski estate and the Zgrzebnioka estate). At the "Zandka" estate in Zabrze, a survey was conducted with 112 residents and 11 in-depth interviews with older residents, and the narrative interviews with 25 priests from the Archdiocese of Katowice and Częstochowa (southern Poland). In all these studies, the elderly who were respondents were treated as users of their apartments, buildings, housing estates or city districts. The purpose of this research was, among others, to learn the feelings and experiences, satisfied and unmet needs related to such aspects of the residential environment such as, inter alia, neighborly bonds, social support, forms of activity, and architectural barriers ${ }^{7}$.

\section{The House for Retired Priests as a standard facility with regard to universal design criteria}

The best test of the value of the idea of universal design is its usability which means it can be used in practice. A good strategy for presenting the values of such an idea is therefore to show an example of a residential environment for the elderly who meets the criteria that are derived from this idea. It is easier to observe such features on a small scale than on a large scale. Therefore, I will present them on the example of a 24-hour facility for senior citizens, which is a small object in the architectural and urban sense, and is also a place of everyday life and permanent residence for a small community of retired priests of several dozen people. The subject of short characteristics in terms of convergence with the idea of universal design will be the House for Retired Priests in Katowice, whose inhabitants were examined both as part of the aforementioned Polish research subproject PolSenior (2007-2011), as well as the

(project manager), dr Barbara Rożałowska, dr Brygida Smołka-Franke, dr Jarosław Mikołajec. As a result of the research, a monograph was created: Niezabitowski, Rożałowska (eds.) (2010).

${ }^{6}$ Research project No. N N 116430637 entitled Wspótczesne trajektorie kaptaństwa i adaptacji księży do życia na emeryturze. Przypadki duszpasterzy parafialnych diecezji województwa ślaskiego [Contemporary trajectories of priesthood and adaptation of priests to retirement. Cases of parish priests from the dioceses of Silesia] (20092011) financed by the Ministry of Science and Higher Education of Poland.

${ }^{7}$ I summarized the analyses of the data collected as a result of these four research projects in my habilitation monograph. See: Niezabitowski (2018a). 
own author's project financed by the Ministry of Science and Higher Education of Poland regarding the adaptation of priests to their lives on retirement (Niezabitowski, 2014a, 2014b). In the light of the analyses that I conducted alone or with a team as part of 2 research projects, it has the following architectural and social features corresponding largely with the idea of universal design:

1. Elimination of barriers (impediments), e.g. installation of elevators despite only 2 floors in the building - encouraging getting out of your room and moving freely in the building, wanted activity and social participation, as well as installation of ramps for people in wheelchairs.

2. Creating infrastructure conducive to social integration - a swimming pool, salt cave, and thus creating conditions to meet the needs of various groups of users, not only disabled people and the elderly living in the House for Retired Priests or the adjoining Care and Therapy Center, but also people from outside these care settings and of different ages.

3. Organized voluntary activities for residents - priesthood services giving self-esteem, feeling of being needed, and also integrating with the wider community (integrating the institution with the local community is an important criterion in the evaluation tools of the institution's functioning as part of the $\mathrm{MEAP}^{8}$ method (Moos, and Lemke, 1984, 1996; Scheidt, 1998; cf. Niezabitowski, 2018, 2019).

4. Does not isolate, does not separate, and connects with the rest of society - gives access to interactions with other social categories and age groups.

5. Gives physical (spatial) and transport access to services, institutions and social interactions - favorable location, i.e. close to the city center, exit to the motorway connecting with many cities of the agglomeration, also close to a seminary important for the social identity of priests.

An empirical argument in favor of the thesis that the residential environment is universally designed if it is as broadly socially integrated as possible, should be the statements of retired priests confirming the benefits of priesthood services organized for them by the House for Retired Priests. Here is a sample statement showing the important function of this activity: "[...] People also often ask, priests from different parishes ask for help [...] for different parishes this House for Retired Priests is such a stepping stone, because if something happens and there is a need, they can count on us, they can receive help especially in the form of a priest who will preach, confess. There are those who can't do it anymore, but there are also those who can. It serves us so well" (74 years old, living in the House for Retired Priests, Archdiocese of Katowice). In the last sentence, the respondent explicitly expresses his satisfaction with his involvement in priesthood; shows that it positively affects his quality of life.

\footnotetext{
${ }^{8}$ MEAP is a Multiphasic Environment Assessment Procedure invented to evaluate the performance of special institutions for elderly people (e.g. nursing homes, day care centers) in many interrelated aspects.
} 
In turn, the statement of another priest shows how important is the institution of services organized by the House of Retired Priests. It describes the phenomenon as a kind of "pastoral emergency": "I also say it, this is a priest's rental, and here we have the slogan that our plant provides all pastoral services in the country and abroad" ( 73 years old, the House for Retired Priests, Archdiocese of Katowice).

The great significance of this institution is revealed here, which is meeting the needs of parish communities in the region. Thanks to this, the institution which is a special home for priests is well integrated with the local communities of various parishes in the diocese, in Poland and abroad. Describing his regular pastoral activity when being retired, the same priest illustrates how his commitment responds to the needs vocalized by "priesthood": "Every Saturday, it is so permanent, and in addition I replace the priest from Piotrowice on Thursdays, from 1 to 3 p.m. - two hours. Such a two-hour duty there in the cathedral confessional. And sometimes, if some priest is not available, the priest from the cathedral calls us and they ask us to replace him. So we go" (73 years old, the House for Retired Priests, Archdiocese of Katowice).

\section{Needs and deficiencies declared by senior respondents as a confirmation of the idea of a universally designed residential environment}

The example (case) of the House for Retired Priests presented above illustrates the importance of the idea of designing a universal residential environment. It concerns a small architectural, urban and social scale. This idea also makes sense in relation to housing estate, which I will illustrate with the needs and deficiencies articulated by the respondents of the research referred to in the introduction.

A friendly environment and housing, as I mentioned earlier, is a priority according to Madrid International Plan of Action on Aging (United Nations, 2002). Meanwhile, many senior citizens experience barriers to meeting their needs in their housing environment and other discomfort in this sphere that reduces their quality of life.

The implementation of the PolSenior ${ }^{9}$ project has shown that just over a third $(35.2 \%)$ of respondents in this survey experience the negative effects of technical defects in apartments and the impact of architectural barriers hindering everyday life; $20 \%$ of people aged 55-64 years, $23.3 \%$ of seniors from the cohort $65-74$ years and $67.5 \%$ aged $75-79$ are affected by these inconveniences (Bartoszek et al., 2012). On the other hand, $11.4 \%$ of seniorrespondents from the age group 70-74 or over 1/5 (22.4\%) from the age group 85-89 declared

\footnotetext{
${ }^{9}$ Cited percentage data from the part of Poland-wide PolSenior research on the residential environment of Polish senior citizens was also discussed in: Niezabitowski (2018a), pp. 40-41. See also Niezabitowski (2018b), pp. 3031.
} 
that there were architectural barriers hindering leaving home. In addition, empirical material collected in these studies shows that barriers (inconveniences) the most frequently mentioned by senior respondents are: high and steep stairs (52.6\%), no elevator (47.8\%), no ramp to the building for people moving on a wheelchair (30.3\%), no handrails and handles $(25.2 \%)$ (Bartoszek et al., 2012).

The analyses that I personally carried out as a part of the research, in which I was the head or contractor, allowed me to highlight the nature of problems experienced by senior citizens related to architectural barriers causing environmental stress and the way of experiencing this stress. I would like to draw attention to several barriers of this type.

\subsection{Lack or too few benches and handrails ${ }^{10}$}

In the immediate vicinity of housing estates, senior inhabitants lack places where you can sit when you are tired of walking or when a sense of balance is disturbed, which may result in a fall and injury: "[...] I have such a shaky balance and I need to rest from time to time. More benches would be useful for old people in these surroundings" (F, 83 years old, Superjednostka housing estate, Katowice).

When the balance of the elderly becomes unstable, the next necessary adaptation of the building expected by senior residents is handrails, allowing them to grip firmly and confidently, and thus maintain a stable body position - static as well as in motion and feel safe. Lack of such a sense of security can be a serious barrier to leaving the apartment and building. One of the respondents to the PolSenior survey describes this issue in a very short and specific way: "Handrails in the corridor could be useful so that I could grasp at them" (F, 59 years old, Superjednostka housing estate, Katowice).

\subsection{Too heavy entrance door to a building}

Another major source of environmental stress for older residents is too heavy door, placing too much physical resistance to overcome when opening or holding it when a wheelchair or walker needs to be passed. This is another situation where it is difficult to maintain balance. A 59-year-old respondent of the PolSenior research subproject, currently disabled for years, describes her inconvenience with the door like this: "[...] In the corridors, these doors are so heavy that it's very hard to open if you move on a wheelchair. They're heavy on the cage" ( $F, 59$ years old, Superjednostka housing estate, Katowice).

\subsection{Lack of a lift or the lift that doesn't stop on each floor}

Old age and reduced physical efficiency mean that climbing stairs causes great effort and fatigue, over time it is the reason for avoiding climbing stairs and increases the need for a lift.

\footnotetext{
${ }^{10}$ Descriptions of architectural barriers experienced by older people (the issue of benches and handrails, too heavy entrance door to the building, problems with the elevator and insufficient support, infrastructure and services) have been also presented in my other publication. See Niezabitowski (2018b), pp. 32-34.
} 
The presence of a lift on a given floor even determines the perception and evaluation of this floor by senior inhabitants. How important this lift which stops on each floor is shown by the following statement by one of the residents of the Katowice "Super Unit", who assesses her apartment in the context of the floor: "Not quite good. I used to like it, but now I fell lack of a lift on my floor" (F, 76 years old, Superjednostka housing estate, Katowice). Another respondent from the same estate, who is on a wheelchair (suffering from multiple sclerosis for 20 years) positively assesses her floor precisely because the lift stops there: "[...] it is important that there is a lift available on my floor, because it is the most important" ( $\mathrm{K}, 59$ years old, Superjednostka housing estate, Katowice). Even a 70-year-old architect with many years of designer experience, the owner of a private design office, is convinced that a lift is a necessary element of building equipment, regardless of the number of floors. He says about it in this way: "This is the problem of the entire Zgrzebnioka housing estate [housing estate in Katowice ed. M.N.], which is not the highest anyway. Now when I design even 3 floors, I put the lift in there. If you design a 3-storey building, then it is automatically of a higher standard, it's not a moloch, so to this standard you should add something adequate to this standard, to improve the image of the building. If it's 4-storey building you absolutely have to put a lift there" (Niezabitowski, 2018a).

\subsection{Lack of support as well as deficiencies in infrastructure and services}

As it results from Polish-German research conducted on three selected housing estates in Katowice, some older residents of these housing estates, who are respondents to this research, experience a lack of support (Niezabitowski, 2018a). This is evidenced by their declarations that in total, at least in two out of five situations - in the event of illness, financial problems, difficulties in shopping, cleaning the apartment, dealing with official matters and loneliness they have to count only on themselves. This problem, as shown in the survey studies, concerns: $31.2 \%$ older (age 65 and over) residents of the Tysiąclecia housing estate, $34.2 \%$ from the Paderewski housing estate and $10.0 \%$ from the Zgrzebnioka housing estate. In the light of these percentages, the small, intimate Zgrzebnioka estate, which is relatively socially homogeneous, is distinguished by the denser, more effective support networks in the neighborhood in comparison with the other two large block estates. As for the other two large blocks of flats, there is a potential risk that a significant percentage of seniors will live without support in their late years (Niezabitowski, 2018a). Similarly, greater value with regard to available support networks is also presented by the small-scale former state-owned farm settlement in Poniszowice near Gliwice, which was the subject of study in the subproject of Poladn-wide PolSenior research. In the case of this housing estate, the largest percentage of senior respondents declared that they could count on the support of their neighbors in the event of illness $-47.5 \%$, while in the other two housing estates - Zatorze in Gliwice and Superjednostka in Katowice, these rates were $26.2 \%$ and $10,8 \%$ respectively. 
The findings made as a result of the PolSenior research's sub-project cited in this article (2007-2011) show that within a neighborly relationship, seniors can get the support they need, but even those who have built the most effective neighborly support networks in their lifetime when they lose physical efficiency and as a result of this independence in their daily self-service expect their family to take care of them (children, grandchildren, etc.) (Niezabitowski, 2010, 2011).

When senior citizens become more and more dependent on others, and their activities of everyday life cause trouble, they would gladly take advantage of other people's services. Some older residents of the Katowice housing estates interviewed in the Polish-German project saw the need to organize catering services for those who no longer can cope with preparing meals on their own (Niezabitowski, 2018a). Here are examples of statements of seniors demonstrating this need: "[...] If there could be a place where older people could get a meal if they can't cook. Such a place in which someone could cook some cheaper dinners for senior residents of our estate. Yes, there could be such a place, because we are aging as a housing estate, at the same time some inhabitants are dying, young people are coming in, but there are a lot of older people here. You know, it should be interviewed, how many people are there, would it pay off to anyone, because today economic conditions determine whether it is worth organizing such services or not" (F, 82 years old, Zgrzebnioka housing estate, Katowice), "[...] it could be useful here, some sort of catering room in which one could get a meal, because it is a whole range of lonely people. It would be nice to eat delicious dinner, cheap and tasty dishes. This would definitely be useful" (F, 74 years old, Zgrzebnioka housing estate, Katowice).

In turn, when old age brings a significant loss of physical efficiency and an increase in the demand for round-the-clock service and care, some older residents of the three analyzed settlements in Katowice signaled the expectation that a 24-hour facility for the elderly should be built within their housing estate (Niezabitowski, 2018a). An illustration of these expectations are the following statements of the respondents: "[...] Well, such a thing would really be useful here. Such a thing, such a house for older people. [...] here a lot of people would go ... there are a lot of people who need help every day. I can manage in everyday life, but there are people who need help constantly" (F, 77 years old, the Tysiąclecie s housing estate) or "Yes. There is a place behind Lidl. [...] Oh, there should be a Nursing Home there. [...] A house which is a fulfillment of a happy peaceful late years fo one's life - this should be built by Piast, because Piast is a good housing cooperative ..." (F, 71 years old, Tysiąclecie settlement). 


\section{Elderly residents' willingness to live with the young in the same housing estate}

The need to live close to young people is pronounced in the light of the interviews with older residents of housing estates in Katowice, studied under the Polish-German project. Here are the examples of respondents' statements illustrating their view on this issue: "[...] no matter where old people live, if they live with younger generations, then these young are ment to help us in need. If you close elderly people in special ghetto, what will be the result?” (F, 64 years old, Superjednostka housing estate, Katowice) or „No, under no circumstances should we be isolated, because support from neighbours have to be available" (F, 64 years old, Superjednostka housing estate, Katowice).

The statements cited above emphasized the belief that separating special housing estates for older people is not a good idea (concept), because it isolates senior citizens and deprives them of necessary support. Another statement also shows that the direct proximity of young people and even children is a positive, pleasant experience. This is also confirmed by some experiments conducted, among others in United States. One of them was implemented in Seattle, where as part of the Intergenerational Education Center (ILC) a retirement home was connected to a kindergarten. The daily interaction and fun of seniors with children reduced blood pressure, improved the body's immunity and general well-being of the former (Mazzini, 2019). Here is a spontaneous statement that expresses the positive feelings of older residents associated with the presence of young people in the estate: "[...] Young people are needed, sure, yes. There are children and these children will make some noise. They run and things are different. I like young people very much, I would even like to see a young person living here. [...] They bring shopping or help in some other way. The old are not always able to cope. The young are needed. Always" (F, 77 years old, Tysiaclecia housing estate, Katowice).

When we consider a housing estate attractive to young and old residents, it must meet the needs and meet the criteria of these various social categories. Some of these criteria or priorities are common, others differ between these two conventionally separated categories. Common priorities for all categories of residents are primarily: acceptable neighbors, favorable location (close to the town center and / or services and institutions), elevators on each floor (particularly relevant for mothers and/or families with young children), easily accessible car parks, close located 24-hour stores, social integration sites (Niezabitowski, 2018a). Priorities specific to elderly residents include: location of the nursing home or other 24-hour facility for senior citizens within the estate and/or in its vicinity, a point of supply with daily food for older people who do not cook themselves. There is also a potential conflict between generations. This applies to discos and other places of social integration of young people, which emit a lot of noise, unacceptable for seniors. It is also worth paying attention to the importance of greenery, favorably affecting residents of all ages and representing various social categories, which older 
respondents of research in housing estates often mention (Niezabitowski, 2018a; see Ottosson, and Grahn, 2005; Zaniewska, 2005).

A positive note is the feeling or conviction of some residents, regardless of their age, that their housing estate is attractive to all social categories, including senior citizens, and that determines their high quality (standard) - good adaptation to current social needs, taking into account demographic processes (including aging). Here is an example of a statement confirming this viewpoint of respondents: "[...] this is a very good housing estate, you know it is close to everywhere, it's ok, just nice to live here in old age" (M, 24 years old, Zgrzebnioka housing estate, Katowice), "Basically, it can be said that it is a universal estate. There are lifts for pensioners so it is easy to move between floors, playgrounds for children. It is a housing estate for everyone (M, 64 years old, Paderewski housing estate, Katowice), "In my opinion, everyone will find something for themselves. Older people are close to everything and greenery, children have a place to play, and young people will find something for themselves. Here is a library so they can study (M, 65 years old, Paderewski housing estate, Katowice).

\section{Conclusion}

The last of the quoted statements of the respondents - residents of the surveyed housing estates in Katowice shows that the idea of a universal housing estate probably has a resonance for them, i.e. the residents themselves are aware that their residential environment should be prepared for every stage of life, including old age. This means the possibility of satisfying the needs of various groups of residents, and therefore the readiness of housing estate managers to provide social and technical infrastructure to meet these needs. The assessment of these needs should be based on sound demographic and sociological research. SWOT analyses of housing estates should be prepared for each of the groups and the general population in order to implement current imperatives and plan strategic decisions for the coming years. The obvious equipment of buildings erected now and in the future must be a lift, regardless of the number of floors. The architects' world in Poland is already maturing to accept this standard. This and other standards related to the physical impairments of older people must be included in building law in the coming years.

The idea of universal design should be implemented at various structural levels of social life, including both a large housing estate and a smaller apartment or a 24-hour facility for the elderly, as staying in it sometimes becomes a necessity.

It is important that the transition to the facility does not have to be a social moratorium of the old person, that it does not mean total exclusion from social life, alienation. That this kind of facility would not be a ghetto, an isolated enclave, but an area of social life, vibrant with life, well integrated with the local community and the needs of other generations or social groups. 
It becomes possible, among others, when it is possible to organize activities which satisfy pensioners. In this respect the example of the House for Retired Priests cited and analyzed, just like the House for the Senior Actor in Skolimów, seems to be a model unit, as there are activities organized for seniors there which satisfy them and at the same time respond to the needs of the social environment.

\section{References}

1. Bartoszek, A., Niezabitowska, E., Kucharczyk-Brus, B., and Niezabitowski, M. (2012). Warunki zamieszkania seniorów - główne ustalenia badawcze. In: M. Mossakowska, A. Więcek, and P. Błędowski (Eds.), Aspekty medyczne, psychologiczne, socjologiczne $i$ ekonomiczne starzenia się ludzi w Polsce [Medical, psychological, sociological and economic aspects of the aging of people in Poland] (pp. 511-530). Poznań: Termedia Wydawnictwa Medyczne.

2. Florida, R. (2004). The Rise of the Creative Class: And How it's Transforming Work, Leisure, Community and Everyday Life. New York: Basic Books.

3. Frąckiewicz, L. (1972). Warunki i potrzeby mieszkaniowe ludzi starych $w$ miastach województwa katowickiego. Warszawa: Instytut Gospodarki Mieszkaniowej.

4. Granovetter, M.S. (1973). The Strength of Weak Ties. American Journal of Sociology, 78, pp. 1360-1380.

5. Goldsmith, S. (1963). Designing for the Disabled. London: RIBA Publications.

6. Goldsmith, S. (1997). Designing for the Disabled. The New Paradigm. New York: Routledge.

7. Goldsmith, S. (2000). Universal Design. A Manual of Practical Guidance for Architects. Oxford, Boston, Johannesburg, New Delhi: Architectural Press.

8. Iwarsson, S., and Slaug, B. (2001). The Housing Enabler. An Instrument for Accessing and Analyzing Accessibility Problems in Housing. Lund: Studentlitteratur.

9. Mazzini, M. (2019). Plan na starość. Przeglą, 26.

10. Moos, R.H., Lemke, S. (1984). Multiphasic Environmental Assessment Procedure (MEAP). Stanford: University Medical Center.

11. Moos, R.H., and Lemke, S. (1996). Evaluating Residential Facilities: The Multiphasic Environmental Assessment Procedure. Thousand Oaks: Sage Publications.

12. Niezabitowski, M. (2010). Relacje sąsiedzkie i wsparcie społeczne osób starszych w środowisku zamieszkania. Przegląd Socjologiczny, 4, pp. 61-82.

13. Niezabitowski, M. (2011). Relacje społeczne ludzi starszych w środowisku zamieszkania aspekty teoretyczne i empiryczne. Acta Univeristatis Lodziensis. Folia Sociologica, 38 , pp. 13-32. 
14. Niezabitowski, M. (2013). Badania socjologiczne jakościowe - wywiady. In: E. Niezabitowska, A. Bartoszek., B. Kucharczyk-Brus, and M. Niezabitowski, Środowisko zamieszkania polskich seniorów w badaniach interdyscyplinarnych: studia przypadków na wybranych przykładach [Residential environment of Polish senior citizens in interdisciplinary research: case studies on selected examples] (pp. 224-250). Katowice: Wydawnictwo Naukowe „Śląsk”.

15. Niezabitowski, M. (2014a). Proboszcz na emeryturze. Wybrane aspekty psychospołeczne w świetle teorii i wywiadów. Ślaskie Studia Historyczno-Teologiczne, 2, pp. 361-384.

16. Niezabitowski, M. (2014b). Procesy biograficzne w analizie adaptacji księży do środowiska zamieszkania na emeryturze. Wybrane aspekty psychospołeczne. Przegląd Socjologii Jakościowej, 4, pp. 80-105.

17. Niezabitowski, M. (2018a). Środowisko zamieszkania $w$ doświadczeniu osób starszych. Wybrane aspekty psychospoleczne w ujęciu socjologicznym [The Residential Environment as Experienced by the Elderly. Selected psychosocial aspects in the scope of sociology]. Gliwice: Wydawnictwo Politechniki Śląskiej.

18. Niezabitowski, M. (2019). MEAP as a method of assessing institutions for elderly people. Scientific Papers of Silesian University of Technology. Organization and Management Series, 140, pp. 239-257. doi: https://dx.doi.org/10.29119/1641-3466.2019.140.20.

19. Niezabitowski, M. (2018b). Kilka uwag o problemach środowiska zamieszkania na tle potrzeb osób starszych dotyczących tej sfery. Exlibris. Biblioteka Gerontologii Społecznej, 15, 1-2, pp. 26-42.

20. Niezabitowski, M., and Rożałowska, B., (Eds.) (2010). Ludzie i instytucje w procesie przemian miejskiej społeczności lokalnej. Studium socjologiczne na przykładzie osiedla Zandka $w$ Zabrzu [People and institutions in the process of transformation of the local community. A sociological study on the example of the Zandka estate in Zabrze]. Gliwice: Wydawnictwo Politechniki Śląskiej.

21. Ottosson, J., and Grahn, P. (2005). A comparison of leisure time spent in a garden with leisure time spent indoors: on measures of restoration in residents in geriatric care. Landscape Resarch, 30, pp. 23-55.

22. Piotrowski, J. (Ed.) (1973). Miejsce człowieka starego $w$ rodzinie i społeczeństwie. Warszawa: PWN.

23. Synak, B. (Ed.) (2003). Polska starość. Gdańsk: Wydawnictwo Uniwersytetu Gdańskiego.

24. Scheidt, R.J. (1998). The Social Ecological Approach of Rudolf Moos. In: R.J. Scheidt, and P.G. Windley (Eds.), Environment and Aging Theory: A Focus on Housing (pp. 111-139). Westport, Connecticut, London: Greenwood Press.

25. Scheidt, R., and Windley, P. (2006). Environmental Gerontology: Progress in the PostLawton Era. In: J. Birren, and W. Schaie (Eds.), The Psychology of Aging (pp. 105-125). San Diego: Elsevier. 
26. Stula, S. (2012). Living in Old Age in Europe. Current Developments and Challenges: Working Paper No.7 of the Observatory for Sociopolitical Developments in Europe, German Association for Public and Private Welfare, Berlin (DV). Retrieved from http://www.sociopolitical-observatory.eu/en/publications.html, 30.09.2017.

27. Szatur-Jaworska，B. (2012). Aktywne starzenie się i solidarność międzypokoleniowa $\mathrm{w}$ debacie międzynarodowej [Active aging and intergenerational solidarity in international debate]. Problemy Polityki Społecznej. Studia i Dyskusje, 17, pp. 15-28.

28. United Nations (2002). Political Declarations and Madrid Plan of Action on Ageing. New York. Retrieved from https://www.un.org/development/desa/ageing/madridplan-ofaction-and-its-implementation.html, 30.05.2020.

29. Universaldesign.ie/Built-Environment/Building-for-Everyone.

30. Zaniewska, H. (2005). Mieszkania ludzi starszych. In: L. Frąckiewicz (Ed.), Przeszłość i przyszłość polskiej polityki mieszkaniowej. Warszawa: Instytut Pracy i Spraw Socjalnych. 